\title{
RECONSTRUCTION OF AGRICULTURAL LANDS
}

\author{
V. Velkovski* \\ PhD student in Economic Academy "Dimitar A. Tsenov" - Svishtov, Bulgaria
}

\begin{abstract}
The recultivation of the agricultural land has the character of a planning event, inasmuch as its nature and normative justification corresponds to the established technological standard for carrying out such.

In a specific aspect related to the peculiarities of this process on agricultural lands, the legal regulations focus mainly on some details related to potential construction on these lands, while at the same time preserving, respectively improving their productivity.

Within the meaning of Article 12, paragraph 3 of the Law on the Protection of Agricultural Land, the use of recultivated agricultural land for non-agricultural purposes is possible by changing its purpose.

According to the text of Article 14, Paragraph 1 of the Law on the Protection of Agricultural Land, the construction of agricultural land from first to sixth category is carried out only after removal of the humus layer, which, according to the provisions of Article 15, paragraph 1 of the Law on the Protection of Agricultural Land, is used for reclamation of disturbed terrains.

If the terrains do not have the characteristics of disturbed, the humus layer is used to improve the productive qualities of the low-productive lands.

The normative requirements regarding the disturbed agricultural terrains and the necessity to carry out recultivation measures on them are regulated in the text of Article 3, paragraph 1 of Ordinance No 26 on rehabilitation of damaged terrains, improvement of low-productive lands, seizure and utilization of humus layer. Reclamation is necessary and feasible:

a / where the affected terrain will be used for agricultural purposes;

$\mathrm{b} /$ when the surface elevation is equal to the height of the neighboring properties;

$\mathrm{c} /$ when road accessibility to the land subject to recultivation is ensured.

Besides the above mentioned requirements, the requirement for ensuring the sustainability of the recultivated terrain is regulated.

This resistance is associated with ignoring the possibility and the danger of collapsing, sliding and sliding, and when creating terraces, their slope must ensure the stability of the earth masses.

The text of Article 4 of Ordinance No 26 regulates the two-stage process of recultivation, which differentiates two groups of reclamation: technical and biological.

Technical recultivation covers a set of events that start with cleaning and preparation of disturbed terrain, seizure and transport of earth masses, alignment and landscaping.

When the terrain has acquired a final appearance, the norm requires the actual, subject of the recultivation activity transportation and spreading of the humus layer.

According to the regulation of art. 2, para 3, item 2 and item 3 of Ordinance № 26, suitable materials for the creation of an upper layer for reclamation of damaged terrains, which must have a humus layer thickness of 30/35 $\mathrm{cm}$, are also, the appropriate horizon of the soil profile, which is inhabited by small microorganisms and the deeper layers to be treated.

The use of such materials is the subject of the second stage of the reclamation process - the stage of biological recultivation, which is classified in the text of Article 4, item 2 of Ordinance No 26 as a complex of agro-technical, agrochemical, technological and meliorative activities for restoration of the productivity of reclaimed areas for a 5year period after the technical reclamation.
\end{abstract}

Key words: The recultivation, The agricultural land, legal regulations, construction, disturbed terrains, the humus layer, low-productive lands, Technical recultivation, category and recultivating activities.

\section{INTRODUCTION}

According to the text of Art. 1, par. 1 and 2 of Ordinance № 26 on the reclamation of disturbed terrains, the improvement of weak

\footnotetext{
*Correspondence to: VALERI VELKOVSKI, PhD student in Economic Academy "Dimitar A. Tsenov" Svishtov, Bulgaria, e-mail: jurist57@abv.bg
}

productive lands, the seizure and utilization of the humus layer - issued by the Minister of Agriculture and Food Industry, the Minister of the Environment, the Minister of Territorial Development and construction and the Forestry Committee of the Council of Ministers [www.lex.bg], the reclamation of 
disturbed terrains covers a complex of engineering, meliorative, agricultural, forestry and other activities, the implementation of which leads to restoration of the disturbed ones and improving the landscape.

Reclamation restores land use for agricultural or forestry use.

This gives reclamation the importance of an important and necessary event, especially as regards farmland.

The subject of the report is the recultivation of agricultural land as a legal practice.

In this respect, some legal norms from the legislative package concerning the reclamation processes of the agricultural lands in the Republic of Bulgaria are subject to consideration.

The aim of the author is to mark the basic points in the legislative framework, the imperative nature of most of them and the legislative privileges granted to the developers of the reclamation processes.

\section{The recultivation of agricultural land as an organizational event.}

The recultivation of the agricultural land has the character of an organizing event, in so far as its nature and the normative justification correspond to the established technological standard for carrying out such.

In a specific aspect related to the peculiarities of this process on agricultural lands, the legal regulations focus mainly on some details related to potential construction on these lands, but at the same time preserving, respectively improving their productivity.

Within the meaning of Article 12 (3) of the Agricultural Land Conservation Act [www.lex.bg], the use of recultivated agricultural land for non-agricultural purposes is possible by changing its purpose.

Under the terms of Article 14 (1) of the Agricultural Land Conservation Act, the construction of agricultural land from first to sixth category shall be carried out only after removal of the humus layer, which, according to the provisions of Article 15, paragraph 1 of The Agricultural Land Conservation Act is used to recultivate damaged plots.

If the terrain does not have the characteristic of the disrupted, the humus layer is used to improve the productive qualities of the lowproductive lands.

The normative requirements regarding the disturbed agricultural terrains and the necessity to carry out recultivation measures on them are regulated in the text of Article 3, paragraph 1 of the above-mentioned Ordinance No 26 on recultivation of damaged terrains, improvement of low-productive lands, seizure and utilization of the humus layer.

Reclamation is necessary and feasible:

a / when the affected terrain will be used for agricultural purposes;

b / when the surface elevation is equal to the height of the neighboring properties;

c / when road accessibility to the land subject to recultivation is ensured.

Besides the above mentioned requirements, the requirement for ensuring the sustainability of the recultivated terrain is regulated.

This resistance is associated with ignoring the possibility and the danger of collapsing, sliding and sliding, and when creating terraces, their slope must ensure the stability of the earth masses.

The text of Article 4 of Ordinance No 26 regulates the two-stage process of recultivation, which differentiates two groups of reclamation: technical and biological.

Technical recultivation covers a set of activities that start with cleaning and preparation of disturbed terrain, seizure and transportation of earth masses, alignment and landscaping.

When the terrain has acquired a final appearance, the norm requires the actual, subject of the recultivation activity transportation and spreading of the humus layer.

According to the regulation of art. 2, para 3, item 2 and item 3 of Ordinance № 26, suitable materials for the creation of an upper layer for reclamation of damaged terrains, which must have a humus layer thickness of $30 / 35 \mathrm{~cm}$, are also, the appropriate horizon of the soil profile, which is inhabited by small microorganisms and the deeper layers to be treated.

The use of such materials is the subject of the second stage of the reclamation process - the stage of biological recultivation, which is classified in the text of Article 4, item 2 of 
Ordinance No 26 as a complex of agrotechnical, agrochemical, technological and meliorative activities for restoration of the productivity of reclaimed areas for a 5-year period after the technical reclamation.

The lands for reclamation shall be determined simultaneously with the site of the main site pursuant to Art. 21 of the Agricultural Land Conservation Act and Section I of Chapter Five of its Implementing Regulations or by the order of Chapter Four of these Rules for nonobservance of the the previous texts.

\section{Categorization of agricultural lands - legal regulations.}

According to the text of art. 1, para 1 to 4 , including the Ordinance on the categorization of agricultural land in case of change of its destination, adopted by Decree № 261 of 17.10.1996, amended SG. No.90 of 24 October 1996, Am. and completed SG. No. 93 of 9 November 2018 [www.lex.bg], the agricultural land in the change of its purpose is categorized in 10 categories according to the productivity of the soils, the climatic conditions, the relief features, the technological qualities of the land, the suitability and the production of different types of crop production and the imposed restrictions of land use under the conditions and by the order of this Ordinance.

The categories are determined by the average bonus score as follows:

1. first category - lands with a ball above 90 ;

2. second category - lands with ball from 81 to 90;

3. third category - lands with a ball of 71 to 80 ;

4. fourth category - lands with a ball from 61 to 70 ;

5. fifth category - lands with a ball from 51 to 60 ;

6. sixth category - lands with a ball from 41 to 50 ;

7. seventh category - land with ball from 31 to 40 ;

8. eighth category - lands with a ball from 21 to 30 ;

9. ninth category - lands with a ball from 11 to 20;

10. tenth category - lands with a ball up to 10 incl.

Not being categorized under the order of para. (2) shall be defined as a land built with buildings and facilities occupied by opencast mines, quarries, embankments, tailing ponds, landfills and other landfills, water areas (rivers, lakes, dams, swamps, wetlands) or sand, gravel, gullies, gullies, gullies and trenches if they are found on the ground material for land division.

The category of land, which is a dirt road, and land occupied by construction and other waste with a preserved soil profile is determined according to the category of adjacent agricultural land.

According to the regulation of Article 3 of this Ordinance, the request for the issuance of an act for the categorization of agricultural land, the purpose of which is proposed to be changed, as well as in cases where the land is ecologically polluted or a categorization of a recultivated area intended for agricultural use, is sent to the Regional Directorate of Agriculture at the Ministry of Agriculture, Food and Forests on the location of the land.

To the request under para. 1 shall be applied: - a notary deed or other land ownership document with a reflection of category and accompanied by a sketch; when the land category is not reflected in the land ownership document, a land registry certificate issued by the municipal agricultural office for reimbursement of ownership;

- for the routes of the linear objects - a preliminary project under Art. 126, para. 6, item 1 of the Spatial Development Act and a register of the affected properties, and for sites - sketch of the property / properties in the coordinate system of the cadastral map;

- certificate of soil pollination according to Art. 30 , para. 1, item 4 of the Implementing

Regulations for the Protection of Agricultural Land.

In the case of a change in the designation of the agricultural land for non-agricultural purposes, for which the Land Conservation Act and its implementing regulations provide that no procedure for the approval of a site or a route for design is carried out, it shall be rendered in force detailed plan.

In the norm of Art. 5 of the Regulation is a regulation which stipulates that when agricultural land has not yet been categorized and the soil cover is not damaged, it is categorized by expertise and when the construction of buildings and facilities has been made on the land without changing its purpose, is categorized according to adjacent lands or by expertise. 
The imperative of para 3 is categorical, according to which recultivated areas, intended for agricultural use, shall be categorized under the conditions and by the order of this Ordinance.

\section{Organisms for recultivation of} agricultural lands.

The authority that establishes the land for reclamation is the Agricultural Land Commission.

The decision of the Commission is the basis for the preparation of the relevant project.

Each such project is developed simultaneously with the project for the main site or as a standalone project.

The projects for land reclamation, land improvement and humus recovery are coordinated with the Minister of Agriculture, Food and Forestry, Agricultural Land from the State Land Fund and the mayor of the respective municipality - for the municipal agricultural lands.

The Expert Council referred to in Article 10, paragraph 2 of the Implementing Regulations for the Law for the Conservation of Agricultural Lands adopted by Decree of the Council of Ministers No 240 of 24.09.1996, SG. No. 84 of 4 October 1996, amend. and completed SG. No. 93 of 9 November 2018 [www.lex.bg] is the body to which the examination and approval of the prepared and coordinated project is assigned, according to the text of Article 18, paragraph 1 of Ordinance No. 26.

The very approval of the project is entrusted to the following functions:

Investor of the Site, the Mayor of the Municipality and the Minister of Agriculture, Food and Forestry.

The site investor approves the project when rehabilitating terrains when they are expropriated for state and municipal needs and the value of the reclamation is included in the site's estimated value.

The mayor of the municipality approves the reclamation project when the reclaimed terrain is municipal property and the recultivation is done with municipal funds.
The Minister of Agriculture, Food and Forestry approves the project for recultivation of land which is state property and the reclamation is carried out with state resources.

A subsequent act of technical recultivation is the act of acceptance, which takes place at the same time as the acceptance of a relevant site or as a separate site under the procedure stipulated in the Implementing Regulations for the Law for the Conservation of Agricultural Lands.

In the case of defects in technical reclamation established by the Commission, these defects during the first five years are eliminated by the investor of the site or the technical reclamation contractor.

In addition, the investor is obliged to hand over the biological reclamation project to the owner / user / land.

On the basis of a contract, it provides funds for the implementation of the biological recultivation.

In the case of technical and biological recultivation carried out by a natural or legal person, the same shall be adopted by a commission appointed by the mayor of the municipality.

According to the text of Article 21, paragraph 1 of Ordinance No 26, recultivated land, which is intended for agricultural purposes, is subject to categorization.

The categorization shall be carried out in accordance with the ordinance for the categorization of the agricultural land upon change of its purpose.

Charges for the categorization of reclaimed lands are paid by the investor of the site (s) under the current tariffs.

Following the adoption of the recultivated terrain act is the act of assigning the recultivated land to the respective land fund.

The reclaimed state agricultural land is included in the State Land Fund and the reclaimed municipal land is included in the municipal land fund of the respective municipality.

In the text of Article 22, paragraph 1 of Ordinance No 26, a legal opportunity is 
granted to the investor for free use of agricultural land.

When an investor on a state or municipal site has paid the state fee, paid the land to his former owners, and has reclaimed with funds from the value of the site, he may want to consume the legal right granted to him for the land to be given to him free of charge agricultural use.

The land is granted by order of the Minister of Agriculture, Food and Forestry, respectively, when the land is assigned to the state land fund or the mayor of the respective municipality when the land is assigned to the municipal land fund.

In the order for granting the land for free use, the following are specified:

- the size of the land;

- land borders;

- the land use period;

- the conditions for its use,

- layered sketches, size and boundaries of the land provided.

In the text of Article 22, paragraph 4 of Ordinance No 26, an alternative option is also provided for reclamation with funds from the budget of the Ministry of Agriculture, Food and Forests.

In such cases, reclaimed agricultural land may not be granted for free use.

\section{CONCLUSION}

In the Regulation of Article 23, paragraph 1 of Ordinance No 26, a legal opportunity was granted to natural and legal persons for the use of state and municipal land.

When the legal entity or natural person has reclaimed state or municipal land with its own funds, it may request the land to be granted for agricultural use.
In these cases, the provision of land for use is made on the basis of a contract between the natural or legal person and the Minister of Agriculture, Food and Forestry, if the land is state property and between the mayor of the municipality and the legal or physical person, if the land is municipal property .

The contract specifies:

- the land use period;

- conditions for use of the land, but as an integral part of the contract is a two-sided certified sketch with the size and boundaries of the land.

\section{REFERENCES}

1. Law on Protection of Agricultural Lands, Prom. SG. issue 35 of 24 April 1996, amend. and completed SG. No. 83 of 9 October 2018.;

2. Ordinance № 26 on rehabilitation of damaged terrains, improvement of lowproductive lands, removal and utilization of the humus layer - issued by the Minister of Agriculture and Food Industry, the Minister of the Environment, the Minister of Territorial Development and Construction and the Forestry Committee to the Council of Ministers.;

3. Ordinance on the categorization of agricultural lands in case of change of the destination, adopted by Decree of the Council of Ministers No 261 of 17.10.1996, Am. SG. No.90 of 24 October 1996, Am.and completed SG. No. 93 of 9 November 2018.;

4. Rules for Implementation of the Law on Conservation of Agricultural Lands, adopted by Decree of the Council of Ministers No 240 of 24.09.1996 amend. SG. No. 84 of 4 October 1996, amend. and completed SG. No. 93 of 9 November 2018.;

5. www.lex.bg. 